\title{
Trends and topics in eye disease research in PubMed from 2010 to 2014
}

Christophe Boudry, Eric Denion, Bruno Mortemousque, Fréderic Mouriaux

Background: The purpose of this study is to provide a report on scientific production during the period 2010-2014 in order to identify the major topics as well as the predominant actors (journals, countries, continents) involved in the field of eye disease.

Methods: A PubMed search was carried out to extract articles related to eye diseases during the period 2010-2014. Data were downloaded and processed through developed PHP scripts for further analysis. Results: 62123 articles were retrieved. 3368 different journals were found, and 19 journals were identified as "core journals" according to Braford's law. English was by far the predominant language. $853182 \mathrm{MeSH}$ terms were found, representing an average of $13.73(S D=4.98) \mathrm{MeSH}$ terms per article. Among these $853182 \mathrm{MeSH}$ terms, 14689 different MeSH terms were identified. Vision Disorders, Glaucoma, Diabetic Retinopathy, Macular Degeneration, and Cataract were the most frequent five MeSH terms related to eye diseases. The analysis of the total number of publications showed that Europe and Asia were the most productive continents, and the USA and China the most productive countries. Interestingly, using the mean Five-Year Impact Factor, the two most productive continents were North America and Oceania. After adjustment for population, the overall ranking positions changed in favor of smaller countries (i.e. Iceland, Switzerland, Denmark, and New Zealand), while after adjustment for Gross Domestic Product (GDP), the overall ranking positions changed in favor of some developing countries (Malawi, Guatemala, Singapore). Conclusions : Due to the large number of articles included and the numerous parameters analyzed, this study provides a wide view of scientific productivity related to eye diseases during the period 2010-2014 and allows us to better understand this field. 


\section{AUTHOR COVER PAGE}

\section{Article Title}

3 Trends and Topics in Eye Disease Research in PubMed from 2010 to 2014

\section{Authors}

5 Christophe Boudry, PhD 1,2,3, Eric Denion, , MD, PhD ${ }^{4}$ Bruno Mortemousque, MD, PhD $6 \quad 5,6$, Fréderic Mouriaux, MD, PhD 5,6

\section{Affiliations}

$8{ }^{1}$ Média Normandie, Normandie Université, Université de Caen Normandie, Caen 9 France

102 URFIST, Ecole Nationale des Chartes, PSL Research University. Paris - France

$113^{3}$ Laboratoire "Dispositifs d'Information et de Communication à l'Ėre Numérique",

12 Conservatoire National des Arts et Métiers, Paris - France

13 4Service d'Ophtalmologie, Caen CHU Côte de Nacre F-14000, France

$14{ }^{5}$ Service d'ophtalmologie, CHU Rennes, 35033 Rennes, France; Univ Rennes 1

$15{ }^{6}$ Faculté de Médecine, F35043 Rennes, France 
17 Christophe. Boudry

18 Média Normandie, Université de Caen Normandie

19 Esplanade de la Paix

20 CS 14032, 14032 Caen Cedex 5, France

21 boudry@enc.sorbonne.fr

22 


\section{MANUSCRIPT TEXT}

\section{Abstract}

25 Background: The purpose of this study is to provide a report on scientific production 26 during the period $2010-2014$ in order to identify the major topics as well as the 27 predominant actors (journals, countries, continents) involved in the field of eye disease.

Methods: A PubMed search was carried out to extract articles related to eye diseases during the period 2010-2014. Data were downloaded and processed through developed PHP scripts for further analysis.

31 Results: 62123 articles were retrieved. 3368 different journals were found, and 19 32 journals were identified as "core journals" according to Braford's law. English was by far 33 the predominant language. $853182 \mathrm{MeSH}$ terms were found, representing an average of $13.73(\mathrm{SD}=4.98) \mathrm{MeSH}$ terms per article. Among these $853182 \mathrm{MeSH}$ terms, 14689 different MeSH terms were identified. Vision Disorders, Glaucoma, Diabetic Retinopathy, Macular Degeneration, and Cataract were the most frequent five $\mathrm{MeSH}$ terms related to eye diseases. The analysis of the total number of publications showed that Europe and Asia were the most productive continents, and the USA and China the most productive countries. Interestingly, using the mean Five-Year Impact Factor, the two most productive continents were North America and Oceania. After adjustment for 41 population, the overall ranking positions changed in favor of smaller countries (i.e. 42 Iceland, Switzerland, Denmark, and New Zealand), while after adjustment for Gross 
43 Domestic Product (GDP), the overall ranking positions changed in favor of some 44 developing countries (Malawi, Guatemala, Singapore).

45 Conclusions : Due to the large number of articles included and the numerous 46 parameters analyzed, this study provides a wide view of scientific productivity related to 47 eye diseases during the period 2010-2014 and allows us to better understand this field. 


\section{INTRODUCTION}

50 Bibliometrics has been defined as the use of statistical methods to analyze a body of

51 literature to reveal historical development through the scientific and quantitative study of

52 publications.(Young \& Belanger, 1983). Applications of bibliometrics are numerous:

53 determining a library purchasing policy (Garfield, 1972), studying the structure of the

54 network of a scientific field (Wallace, Larivière \& Gingras, 2012), and mapping the

55 literature related to a research field such as health literacy (Kondilis et al., 2008) or

56 cancer research (Glynn et al., 2010). Bibliometrics can also evaluate the speed of

57 publication of manuscripts in journals (Chen, Chen \& Jhanji, 2013), allow one to

58 recognize new topics in the literature (Boudry, 2015), or even evaluate research and

59 researchers (Hirsch, 2005). Viewed as an objective and quantifiable assessment of

60 research output, such bibliometrics are inextricably linked with research funding, and an

61 investigator must possess a strong publishing background to obtain the financial grants

62 necessary for further work (Geisler, 2000).

63 Few bibliometric studies have appeared in the literature in the field of ophthalmology.

64 Although some analyses have been done on specific countries,(Kumaragurupari,

65 Sieving \& Lalitha, 2010; Katibeh, Moein \& Javadi, 2011; Schlenker, Manalo \& Wong,

66 2013) continents or territories (Ugolini et al., 2001; Sweileh et al., 2015), sub-specialties

67 (Zhao et al., 2011; Gupta, Bala \& Gupta, 2014; Boudry \& Mouriaux, 2015), or production

68 of a selection of ophthalmologic journals (Kumbar \& Akhtary, 1998; Guerin et al., 2009;

69 Kumar, Cheeseman \& Durnian, 2011; Liesegang, 2011), no attempts have been made

70 to describe the field "eye diseases". The main purpose of this paper is to provide a 
71 report on scientific production in the field of eye diseases. For this, core journals have

72 been identified, and frequency and distribution of MeSH terms in articles calculated.

73 Furthermore, the geographical distribution and the temporal trend of papers published

74 between 2010 and 2014 have been investigated with ad hoc geographical analyses

75 evaluating literature production and weighted according to major socioeconomic 76 variables, i.e. population size and Gross Domestic Product (GDP).

\section{MATERIAL \& METHODS}

78 Data were downloaded from PubMed in Extensible Markup Language (XML) and were 79 processed through developed Hypertext Preprocessor language (PHP) scripts, then 80 were imported to Microsoft Excel 2010 (Microsoft, Redmond, USA) for data processing.

\section{Bibliographic search}

82 The search for papers to be included in this study was carried out on January 16th 83 2015, using the PubMed database (http://www.ncbi.nlm.nih.gov/pubmed), developed by

84 the National Center for Biotechnology Information (NCBI) at the National Library of 85 Medicine (NLM). PubMed was chosen because it is the most widely used in medicine 86 (Falagas et al., 2008). The search strategy was the following: eye diseases [MH] AND 87 journal article [PT] AND 2010:2014 [DP] where MeSH stands for "Medical Subject 88 Headings", DP "Date of Publication", and PT "Publication Type". "Journal Article" 89 includes the following publication types: journal articles, introductory journal articles, and 90 reviews. MeSH is the National Library of Medicine's controlled vocabulary thesaurus 91 (http://www.nlm.nih.gov/pubs/factsheets/mesh.html) and consists of sets of terms 
92 named "MeSH terms" arranged in a hierarchical structure (called a MeSH tree) with

93 more specific terms arranged beneath less specific terms. In the indexing process, 2 to

$9450 \mathrm{MeSH}$ terms are assigned to PubMed documents by a team of trained experts 95 (indexers) to properly identify the content, and indexers always index as specifically as 96 possible ("MEDLINE Indexing Online Training Course," 2015). It is worth mentioning 97 that it is not obligatory for author's keywords to be taken into account by indexers to 98 determine MeSH terms of an article (Boudry, 2015 unpublished data). The MeSH term 99 "Eye Diseases", the definition of which in the NLM-controlled vocabulary thesaurus is 100 "Diseases affecting the eye", was chosen because it covers all diseases of the eye 101 when used in a PubMed search. Indeed, when using a MeSH term in a PubMed search, 102 articles that carry the specified MeSH term are retrieved, but so are all of the articles 103 that carry any of the more specific MeSH terms located beneath it in the tree structure. 104 Thus, searching with the MeSH term "Eye Diseases" automatically includes all the $105 \mathrm{MeSH}$ terms located beneath "Eye Diseases" corresponding to diseases of the eye in 106 general.

\section{Analysis of MeSH terms}

108 As done in other studies (Ugolini et al., 2007, 2010; Ramos, González-Alcaide \& 109 Bolaños-Pizarro, 2013; Monica Neri, 2015), an analysis of the MeSH terms used by

110 PubMed indexers to classify the articles was done by calculating their frequency in the 111 retrieved articles. Check tags, i.e. MeSH terms obligatorily used by indexers to describe 112 recurrent patterns in medical articles, were excluded from this frequency analysis 113 because of their compulsory and recurrent character. They are shown in Supplemental 
114 Table S1. The co-occurrence is the simultaneous association of two identical MeSH

115 terms in different articles. The frequency and the percentage of co-occurrence of the

$116 \mathrm{MeSH}$ terms located beneath the MeSH term "Eye Diseases" in articles has been

117 calculated. Likewise, the frequency of all other MeSH terms not situated beneath the

118 MeSH term "Eye Diseases" retrieved has also been calculated.

119 Analysis of growth of literature

120 The average yearly growth rate of the literature related to eye diseases was calculated

121 as the mean percentage of annual growth rate for the period studied using the equation:

122 Annual Growth Rate $=$ Current Year Total Number of Articles - Previous Year Total

123 Number of Articles/Previous Year Total Number of Articles (Deshazo, Lavallie \& Wolf,

124 2009). The average yearly growth rate was also calculated for the whole PubMed

125 database for the period $2010-2014$.

126 Bradford's law

127 Bradford's law has been used extensively in the information science literature to

128 describe the dispersion of articles in any scientific field (Goffman \& Warren, 1969), or to

129 identify "core journals" of serial titles (Deshazo, Lavallie \& Wolf, 2009; Venable et al.,

130 2014). Bradford's law states that "If scientific journals are arranged in order of

131 decreasing productivity of articles on a given subject, they may be divided into a

132 nucleus of periodicals more particularly devoted to the subject and several groups or

133 zones containing the same number of articles as the nucleus". To identify the core

134 journals containing articles dedicated to eye diseases, Bradford's law was applied by 
135 dividing the journals ranked according to publication output frequency into three groups

136 with each group representing approximately the same number of articles.

\section{Analysis of journals and language of publication}

138 The 2013 Journal Citation Reports (JCR) (Thomson Reuters, New York, USA) was 139 used for Impact Factor (IF) determination and for the ranking of the journal in the 140 category "Ophthalmology" of the JCR. Language of publication was determined using

141 the "Language" field for all articles retrieved. The percentage of papers published in 142 English in the entire PubMed database between 2010 and 2014 was also calculated 143 using the following search strategy: Medline [sb] OR publisher [sb] OR 144 pubstatusaheadofprint AND 2010:2014 [DP] AND journal article [PT] where sb means 145 "subset".

\section{Quantitative and qualitative analysis of publication ouput}

147 A quantitative evaluation of the scientific production related to eye diseases was done 148 by evaluating the total number of articles published for each country. To implement a 149 qualitative evaluation, each article was related to the corresponding journal manually in 150 the JCR 2013 to determine the Five-Year Impact Factor (5-Y IF). If a journal did not 151 have an 5-Y IF, the value zero was assigned to the article. For each country, the 152 cumulative 5-Y IF was calculated as the sum of the 5-Y IF of all articles. The mean Five153 Year Impact Factor (m5-Y IF) was calculated as the cumulative 5-Y IF divided by the 154 number of articles. 
155 For the quantitative and the qualitative evaluation, we calculated the number of

156 publications and the cumulative and m5-Y IF according to countries and continents.

157 The country of affiliation of the first author was determined by the address in the

158 "Affiliation" field. When the country was absent in the address, it was determined from

159 the city or email address using an Internet search engine if necessary. If the name of a 160 country no longer existed (e.g. Yugoslavia), the city was used to find the name of the 161 existing country in 2015. England, Scotland, Northern Ireland, and Wales were grouped 162 into the United Kingdom. Hong Kong was considered as part of China.

164 The GDP is the market value of all officially recognized final goods and services 165 produced within a country in a given period. GDP per capita is often considered an 166 indicator of a country's standard of living (World Bank Group. 167 http://www.worldbank.org/). For each country and each continent, the 5-Y IF GDP index 168 (cumulative 5-Y IF per 1 billion US dollars of GDP) and the 5-Y IF population index 169 (cumulative 5-Y IF per million inhabitants) were calculated using the World 170 Development Indicators from the online databases of the World Bank 171 (http://data.worldbank.org/). The 5-Y IF GDP and the 5-Y IF population index were 172 calculated using the mean GDP and mean number of inhabitants from 2010 to 2013 173 (data for 2014 were not available). Countries were clustered by their continent 174 according to the United Nations classification (United Nations Statistics Division175 Standard Country and Area Codes Classifications.

176 http://unstats.un.org/unsd/methods/m49/m49regin.htm). 
178 RESULTS

179 Journals

180 The search in PubMed resulted in a total of 62123 articles over the period 2010 to

181 2014. We calculated that the average growth rate of literature related to eye diseases

182 was $4.27 \%$. We also calculated that the average growth rate for the whole PubMed

183 database was $6.59 \%$ for the same period. Thus, the difference in growth rates between

184 the growth rate of eye diseases and all scientific production in the PubMed database is

185 equal to $-2.32(4.27-6.59)$, which indicates a moderate interest of the scientific

186 community for eye diseases for the studied period, and a stabilization of publication rate

187 (Michon \& Tummers, 2009).

188 The 62123 articles found in the present study were published in 3368 different journals 189 over the period 2010 to 2014.

190 Fifty-four journals of 58 belonging to the category "Ophthalmology" in the JCR were 191 found in the 3368 journals retrieved. These 54 journals published 29183 articles of the $19262123(46.98 \%)$ that we found in the present study.

193 According to Bradford's law, the total number of articles compared to the number of 194 journals in order of decreasing productivity was divided into 3 zones containing 195 approximatively the same number of articles. The first third of the total number of 196 articles $(n=20779)$ represented the journals $(n=19 ; 0.56 \%)$ that published between 3 197619 and 589 articles (Table 1).. The middle third ( $n=20637$ ) corresponds to the journals $198(n=118 ; 3.5 \%)$ that contained an average number of articles (between 290 and 579 
199 articles), and the last third ( $n=20707)$ includes the "long tail" of journals $(n=3231$; $20095.9 \%$ ) that published the fewest articles (less than 114). It is important to note that 1 201428 journals (42.4\%) published only 1 or 2 articles related to eye diseases over the 5202 year study period.

203 
204 Table 1 Core journals according to Bradford's law (19 most productive journals 205 between 2010 and 2014)

\begin{tabular}{|c|c|c|c|c|}
\hline Journal & $\begin{array}{l}\text { Impact } \\
\text { Factor } \\
\text { (JCR } \\
\text { rank †) }\end{array}$ & $\begin{array}{l}\text { Language of } \\
\text { publication }\end{array}$ & $\begin{array}{l}\text { Number } \\
\text { of articles } \\
\text { related to } \\
\text { "eye } \\
\text { diseases" }\end{array}$ & $\begin{array}{l}\text { Total number of } \\
\text { articles published by } \\
\text { the journal } \\
\text { (percentage of } \\
\text { articles related to } \\
\text { "eye diseases" } \\
\text { relative to the total } \\
\text { number of articles } \\
\text { published) }\end{array}$ \\
\hline $\begin{array}{c}\text { Investigative Ophthalmology \& Visual } \\
\text { Science }\end{array}$ & $3.661(6)$ & English & 3619 & $4955(73.03)$ \\
\hline Ophthalmology & $6.170(2)$ & English & 1575 & $1715(91.86)$ \\
\hline British Journal of Ophthalmology & $2.809(10)$ & English & 1319 & $1496(88.20)$ \\
\hline Retina & $3.177(8)$ & English & 1292 & $1628(79.36)$ \\
\hline American Journal of Ophthalmology & $4.021(5)$ & English & 1235 & $1382(89.35)$ \\
\hline Cornea & $2.360(19)$ & English & 1156 & $1384(83.52)$ \\
\hline $\begin{array}{c}\text { Journal of Cataract and Refractive } \\
\text { Surgery }\end{array}$ & $2.552(15)$ & English & 1082 & $1441(75.10)$ \\
\hline JAMA Ophthalmology $\ddagger$ & $4.488(3)$ & English & 1030 & $1135(90.74)$ \\
\hline PLoS One & $3.534 \S$ & English & 1012 & $82543(1.23)$ \\
\hline $\begin{array}{l}\text { Graefe's Archive for Clinical and } \\
\text { Experimental Ophthalmology }\end{array}$ & $2.333(20)$ & English & 967 & $1174(82.36)$ \\
\hline Molecular Vision & $2.245(21)$ & English & 940 & $1372(68.51)$ \\
\hline Eye & $1.897(26)$ & English & 842 & $958(87.90)$ \\
\hline Acta Ophthalmologica & $2.512(16)$ & English & 780 & $943(82.71)$ \\
\hline Optometry and Vision Science & $2.038(22)$ & English & 709 & $913(77.66)$ \\
\hline $\begin{array}{c}\text { Klinische Monatsblätter für } \\
\text { Augenheilkunde }\end{array}$ & $0.665(53)$ & German, English & 691 & $858(80.54)$ \\
\hline European Journal of Ophthalmology & $1.058(46)$ & English & 667 & $738(90.43)$ \\
\hline $\begin{array}{c}\text { Ophthalmic Plastic and Reconstructive } \\
\text { Surgery }\end{array}$ & $0.914(50)$ & English & 647 & $774(83.59)$ \\
\hline Journal Français d'Ophtalmologie & $0.361(56)$ & French, English & 627 & $688(91.10)$ \\
\hline Experimental Eye Research & $3.017(9)$ & English & 589 & $1013(58.14)$ \\
\hline
\end{tabular}

JCR = Journal Citation Report

207 *Impact factor for 2013

208 † Ranking of journals in the JCR with impact factor in the category "Ophthalmology" (2013). This 209 category includes 58 journals.

$210 \ddagger$ Formerly Archives of Ophthalmology

$211 \S$ JCR Category: Multidisciplinary Sciences 
212 Journal of Cataract and Refractive Surgery and Ophthalmic Plastic and Reconstructive Surgery

213 also belong in the category "Surgery" of the JCR. Molecular Vision also belongs in the category

214 "Biochemistry and molecular biology" of the JCR.

\section{Languages of publication}

216 Thirty-one different languages were identified in the 62123 articles retrieved. The five

217 predominant languages were English ( $n=55$ 829; 89.87\%), German ( $n=1401 ; 2.26 \%)$,

218 French $(n=1132 ; 1.82 \%)$, Chinese $(n=927 ; 1.49 \%)$, and Japanese $(n=641 ; 1.03 \%)$. All

219 other languages amounted to less than 1\%. The percentage of articles in English in the

220 entire PubMed database was $93.49 \%$ for the same period.

\section{MeSH terms for eye diseases}

222 The MeSH term "Eye Diseases" is located beneath the MeSH term "Diseases" in the

$223 \mathrm{MeSH}$ tree. Twenty-seven more specific MeSH terms situated just one level beneath

224 "Eye Diseases" were found in the MeSH tree (Figure 1a). The MeSH tree beneath "Eye

225 Diseases" includes 6 levels. In total, 243 MeSH terms located beneath "Eye Diseases"

226 were found in these 6 levels. As an example, the MeSH tree for the MeSH term

227 "Chorioretinitis" located six levels beneath "Eye Diseases" is described in Figure 1b. 
229 Figure 1. a. MeSH term "Eye Diseases" and the $27 \mathrm{MeSH}$ terms located just one level 230 beneath. b. Example of the MeSH term "Chorioretinitis". L1 to L6: Level 1 to Level 6 in 231 the MeSH tree beneath the MeSH term "Eye Diseases"

a.

All MeSH Categories
Diseases Category

Eye Diseases

Asthenopia (L1)

Cogan Syndrome (L1)

Conjunctival Diseases (L1)

Corneal Diseases (L1)

Eye Abnormalities (L1)

Eye Diseases, Hereditary (L1)

Eye Hemorrhage (L1)

Eye Infections (L1)

Eye Injuries (L1)

Eye Manifestations (L1)

Eye Neoplasms (L1)

Eyelid Diseases (L1)

Lacrimal Apparatus Diseases (L1)

Lens Diseases (L1)

Ocular Hypertension (L1)

Ocular Hypotension (L1)

Ocular Motility Disorders (L1)

Optic Nerve Diseases (L1)

Orbital Diseases (L1)

Pupil Disorders (L1)

Refractive Errors (L1)

Retinal Diseases (L1)

Scleral Diseases (L1)

Uveal Diseases (L1)

Vision Disorders (L1)

Vitreoretinopathy, Proliferative (L1)

Vitreous Detachment (L1) b.

Eye Diseases

Uveal Diseases (L1)

Uveitis (L2)

Panuveitis (L3)

Uveitis, Posterior (L4)

Choroiditis (L5)

Chorioretinitis (L6)

233 Analyzing the 62123 articles, we found $853182 \mathrm{MeSH}$ terms, which represent an

234 average of $13.73(\mathrm{SD}=4.98) \mathrm{MeSH}$ terms per article. Among these $853182 \mathrm{MeSH}$ 
235 terms, 14689 different MeSH terms were identified: 243 were located beneath "Eye 236 Diseases" and 14446 were not located beneath "Eye Diseases". The 20 most frequent $237 \mathrm{MeSH}$ terms located in all the levels beneath the MeSH term "Eye Diseases", and for 238 each $\mathrm{MeSH}$ term, the 5 most co-occurring MeSH terms in articles are presented in 239 Table 2 (for information on the 21st to 50th see Supplemental Table S2). 
240 Table 2 Twenty most frequent MeSH terms retrieved in articles and located in all levels beneath the MeSH term "Eye

241 Diseases" in the MeSH tree and co-occurrence of MeSH terms in articles

\begin{tabular}{|c|c|c|c|c|c|}
\hline $\begin{array}{l}\text { MeSH terms } \\
\text { located } \\
\text { beneath "Eye } \\
\text { Diseases" }\end{array}$ & $\begin{array}{l}\text { Number of } \\
\text { articles } \\
\text { indexed with } \\
\text { this MeSH } \\
\text { term }(\%)\end{array}$ & $\begin{array}{l}\text { Five most co-occurring MeSH terms in } \\
\text { articles with the MeSH term in the first } \\
\text { column ( } \% \text { of co-occurrence) }\end{array}$ & $\begin{array}{l}\text { MeSH terms } \\
\text { located } \\
\text { beneath "Eye } \\
\text { Diseases" } \\
\text { (continued) } \\
\end{array}$ & $\begin{array}{l}\text { Number of } \\
\text { articles } \\
\text { indexed with } \\
\text { this MeSH } \\
\text { term }(\%)\end{array}$ & $\begin{array}{l}\text { Five most co-occurring MeSH terms in } \\
\text { articles with the MeSH term in the first } \\
\text { column (\% of co-occurrence) }\end{array}$ \\
\hline $\begin{array}{l}\text { Vision } \\
\text { Disorders (L1) }\end{array}$ & 3471 (5.59) & $\begin{array}{l}\text { Visual Acuity (34.8) } \\
\text { Visual Fields (19.25) } \\
\text { Retrospective studies (12.79) } \\
\text { Treatment Outcome (12.22) } \\
\text { Tomography, Optical Coherence } \\
(11.93)\end{array}$ & $\begin{array}{l}\text { Corneal } \\
\text { Diseases }(\mathrm{L} 1)\end{array}$ & 1599 (2.57) & $\begin{array}{l}\text { Visual Acuity (28.33) } \\
\text { Cornea (23.08) } \\
\text { Retrospective Studies (21.08) } \\
\text { Treatment Outcome (19.20) } \\
\text { Epithelium Corneal (14.88) }\end{array}$ \\
\hline Glaucoma (L2) & $3145(5.06)$ & $\begin{array}{l}\text { Intraocular Pressure (48.51) } \\
\text { Retinal Ganglion Cells (17.24) } \\
\text { Visual Fields (15.78) } \\
\text { Tomography, Optical Coherence } \\
(15.14) \\
\text { Tonometry, Ocular (15.01) }\end{array}$ & $\begin{array}{l}\text { Sjogren's } \\
\text { Syndrome (L3) }\end{array}$ & 1410 (2.27) & $\begin{array}{l}\text { Salivary Glands (14.89) } \\
\text { Autoantibodies (13.05) } \\
\text { Lupus Erythematosus, Systemic (11.21) } \\
\text { Treatment Outcome }(9.36) \\
\text { Case-Control Studies (8.94) }\end{array}$ \\
\hline $\begin{array}{l}\text { Diabetic } \\
\text { Retinopathy (L2) }\end{array}$ & $3084(4.96)$ & $\begin{array}{l}\text { Diabetes Mellitus, Type } 2 \text { (22.86) } \\
\text { Macular Edema (21.77) } \\
\text { Visual Acuity (18.32) } \\
\text { Retina (17.67) } \\
\text { Tomography, Optical Coherence } \\
(13.59)\end{array}$ & $\begin{array}{l}\text { Macular } \\
\text { Edema (L4) }\end{array}$ & $1399(2.25)$ & $\begin{array}{l}\text { Visual Acuity (52.75) } \\
\text { Tomography, Optical Coherence (49.46) } \\
\text { Diabetic Retinopathy (46.89) } \\
\text { Intravitreal Injections (28.73) } \\
\text { Treatment Outcome (28.31) }\end{array}$ \\
\hline $\begin{array}{l}\text { Macular } \\
\text { Degeneration } \\
\text { (L3) }\end{array}$ & $2756(4.44)$ & $\begin{array}{l}\text { Visual Acuity (35.81) } \\
\text { Antibodies Monoclonal Humanized } \\
(27.58) \\
\text { Angiogenesis Inhibitors (26.96) } \\
\text { Tomography, Optical Coherence } \\
(25.91) \\
\text { Vascular Endothelial Growth Factor A } \\
(21.52)\end{array}$ & $\begin{array}{l}\text { Retinal } \\
\text { Detachment } \\
\text { (L2) }\end{array}$ & $1396(2.25)$ & $\begin{array}{l}\text { Visual Acuity (42.91) } \\
\text { Vitrectomy (36.32) } \\
\text { Retrospective Studies (29.87) } \\
\text { Tomography, Optical Coherence }(26.2 \\
\text { Treatment Outcome (21.56) }\end{array}$ \\
\hline Cataract (L2) & $2656(4.28)$ & $\begin{array}{l}\text { Visual Acuity (30.27) } \\
\text { Cataract Extraction (26.88) } \\
\text { Lens Implantation Intraocular (21.99) } \\
\text { Lens Crystalline (18.19) } \\
\text { Phacoemulsification (17.09) }\end{array}$ & $\begin{array}{l}\text { Optic Nerve } \\
\text { Diseases (L1) }\end{array}$ & 1237 (1.99) & $\begin{array}{l}\text { Optic Disk (39.45) } \\
\text { Intraocular Pressure (33.23) } \\
\text { Retinal Ganglion Cells (31.85) } \\
\text { Tomography, Optical Coherence (30.23) } \\
\text { Visual Fields (29.59) }\end{array}$ \\
\hline Retinal & $2138(3.44)$ & Tomography, Optical Coherence & Uveitis (L2) & $1181(1.90)$ & Treatment Outcome (18.37) \\
\hline
\end{tabular}




\begin{tabular}{|l|l|l|}
\hline Diseases (L1) & & $\begin{array}{l}(24.84) \\
\text { Retina (22.26) } \\
\text { Visual Acuity (20.39) } \\
\text { Fluorescein Angiography (16.00) } \\
\text { Retrospective Studies (12.35) }\end{array}$ \\
\hline Myopia (L2) & 2136 (3.44) & $\begin{array}{l}\text { Visual Acuity (38.13) } \\
\text { Refraction Ocular (31.76) } \\
\text { Keratomileusis Laser In Situ (23.47) } \\
\text { Lasers Excimer (19.48\%) } \\
\text { Retrospective Studies (18.31) }\end{array}$ \\
\hline Glaucoma, \\
Open-Angle (L3) & 2006 (3.23) & $\begin{array}{l}\text { Intraocular Pressure (61.22) } \\
\text { Tonometry, Ocular (22.98) } \\
\text { Visual Fields (22.33) } \\
\text { Prospective Studies (21.09) } \\
\text { Antihypertensive Agents (17.05) }\end{array}$ \\
\hline Eye Diseases & 2005 (3.23) & $\begin{array}{l}\text { Visual Acuity (11.47) } \\
\text { Retrospective Studies (11.27) } \\
\text { Eye Diseases, Hereditary (10.12) } \\
\text { Ophthalmology (9.08) } \\
\text { Eye (8.33) }\end{array}$ \\
\hline Blindness (L2) & 1810 (2.91) & $\begin{array}{l}\text { Visual Acuity (16.46) } \\
\text { Prevalence (11.93) } \\
\text { Magnetic Resonance Imaging (10.22) } \\
\text { Visually Impaired Persons (9.72) } \\
\text { Risk Factors (8.12) }\end{array}$ \\
\hline
\end{tabular}

\begin{tabular}{|l|l|l|}
\hline & & $\begin{array}{l}\text { Retrospective Studies (18.29) } \\
\text { Visual Acuity (16.93) } \\
\text { Autoimmune Diseases (11.85) } \\
\text { Disease Models, Animal (10.84) }\end{array}$ \\
\hline $\begin{array}{l}\text { Choroidal } \\
\text { Neovasculari } \\
\text { zation (L3) }\end{array}$ & 1137 (1.83) & $\begin{array}{l}\text { Angiogenesis Inhibitors (41.60) } \\
\text { Visual Acuity (40.90) } \\
\text { Antibodies, Monoclonal, Humanized } \\
\text { (39.93) } \\
\text { Fluorescein Angiography (38.70) } \\
\text { Macular Degeneration (36.50) }\end{array}$ \\
\hline Behcet \\
Syndrome (L5) & 1106 (1.78) & $\begin{array}{l}\text { Treatment Outcome (17.27) } \\
\text { Case-Control Studies (14.29) } \\
\text { Immunosuppressive Agents (13.29) } \\
\text { Retrospective Studies (11.66) } \\
\text { Genetic Predisposition to Disease (9.95) }\end{array}$ \\
\hline $\begin{array}{l}\text { Retinal } \\
\text { Degeneration } \\
\text { (L2) }\end{array}$ & 1063 (1.71) & $\begin{array}{l}\text { Retina (33.30) } \\
\text { Disease Models Animal (31.89) } \\
\text { Electroretinography (20.70) } \\
\text { Photoreceptor Cells Vertebrate (18.44) } \\
\text { Mice Inbred C57BL (17.87) }\end{array}$ \\
\hline $\begin{array}{l}\text { Tears (46.91) } \\
\text { Ophthalmic Solutions (20.74) } \\
\text { Questionnaires (17.79) } \\
\text { Prospective Studies (17.32) } \\
\text { Syndromes } \\
\text { Cornea (15.98) }\end{array}$ \\
\hline
\end{tabular}


244 Similarly, Table 3 describes the 20 most frequent MeSH terms retrieved in articles and 245 not located beneath "Eye Diseases" (for information on the 21st to 50th see 246 Supplemental Table S3). Among these MeSH terms not located beneath "Eye 247 Diseases", note that some are related to methods of investigation (Tomography, Optical 248 Coherence, Magnetic, Resonance Imaging; Fluorescein Angiography) or type of studies 249 (Retrospective Studies, Follow-Up Studies, Prospective Studies, Cross-Sectional 250 Studies, Case-Control Studies). 
252 Table 3 Twenty most frequent MeSH terms retrieved in articles and not located 253 beneath the MeSH term "Eye Diseases" in the MeSH tree

\begin{tabular}{|l|l|}
\hline MeSH terms & $\begin{array}{l}\text { Number of } \\
\text { articles indexed } \\
\text { with this MeSH } \\
\text { term (\%) }\end{array}$ \\
\hline Visual Acuity & $10938(17.60)$ \\
\hline Retrospective Studies & $8333(13.41)$ \\
\hline Treatment Outcome & $8078(13.00)$ \\
\hline Follow-Up Studies & $5913(9.52)$ \\
\hline $\begin{array}{l}\text { Tomography, Optical } \\
\text { Coherence }\end{array}$ & $5817(9.36)$ \\
\hline Prospective Studies & $5264(8.47)$ \\
\hline Intraocular Pressure & $4185(6.74)$ \\
\hline Risk Factors & $3981(6.41)$ \\
\hline Retina & $3771(6.07)$ \\
\hline Disease Models Animal & $3141(5.06)$ \\
\hline
\end{tabular}

\begin{tabular}{|l|l|}
\hline MeSH terms (continued) & $\begin{array}{l}\text { Number of } \\
\text { articles indexed } \\
\text { with this MeSH } \\
\text { term (\%) }\end{array}$ \\
\hline $\begin{array}{l}\text { Magnetic, Resonance } \\
\text { Imaging }\end{array}$ & $3072(4.94)$ \\
\hline Diagnosis Differential & $2935(4.72)$ \\
\hline Fluorescein Angiography & $2923(4.70)$ \\
\hline Cornea & $2745(4.42)$ \\
\hline $\begin{array}{l}\text { Postoperative } \\
\text { Complications }\end{array}$ & $2654(4.27)$ \\
\hline Cross-Sectional Studies & $2390(3.85)$ \\
\hline Time Factors & $2295(3.69)$ \\
\hline Case-Control Studies & $2278(3.67)$ \\
\hline Visual Fields & $2201(3.54)$ \\
\hline Prevalence & $2177(3.50)$ \\
\hline
\end{tabular}

254 Geographical distribution and socioeconomic factors

255 The determination of the country of the first author was possible for 59060 articles 256 (95.07\%). One hundred thirty-two different countries were identified. As shown in Table 257 4A, the qualitative evaluation with the m5-Y IF by continents led to a new ranking 258 compared with the absolute production (total number of publications): North America 259 and Oceania initially $3^{\text {th }}$ and $4^{\text {th }}$, were respectively first and second when considering 260 m5-Y IF. Geographic distribution by continent of publication was also different after 261 adjustment for 5-Y IF population index and 5-Y IF GDP index (Table 4A and 4C) 
Table 4 Production of articles related to eye diseases, by continent (2010-2014). (A) Based on the total number of publications, (B) Based on the 5-Y IF population index (cumulative 5-Y IF per million inhabitants), (C) Based on the 5-Y IF GDP index (cumulative 5-Y IF per 1 billion US dollars of GDP)

B

\begin{tabular}{|l|l|}
\hline Continent & $\begin{array}{l}\text { 5-Y IF } \\
\text { population } \\
\text { index }\end{array}$ \\
\hline North America & 166.2 \\
\hline Oceania & 158.41 \\
\hline Europe & 70.57 \\
\hline Asia & 9.47 \\
\hline $\begin{array}{l}\text { Latin America and } \\
\text { the Caribbean }\end{array}$ & 4.52 \\
\hline & \\
Africa & 1.47 \\
\hline World & 22.8 \\
\hline
\end{tabular}

C

\begin{tabular}{|l|l|}
\hline Continent & $\begin{array}{l}\text { 5-Y IF GDP } \\
\text { index }\end{array}$ \\
\hline Oceania & 3.69 \\
\hline North America & 3.28 \\
\hline Europe & 2.49 \\
\hline Asia & 1.74 \\
\hline Africa & 0.73 \\
\hline $\begin{array}{l}\text { Latin America } \\
\text { and the } \\
\text { Caribbean }\end{array}$ & 0.47 \\
\hline World & 2.23 \\
\hline
\end{tabular}

267 GDP = gross domestic product; 5-Y IF = five-year impact factor; m5-Y IF = mean five-year impact factor 
268 When analyzing countries, the United States was the most absolute productive country 269 for total number of publications (Table 5A). Among the most productive countries, 15 of 27020 were classified as developed countries (according to the definition of the United 271 Nations). Qualitative evaluation using m5-Y IF highlighted the quality of the scientific 272 production related to eye diseases of some countries (i.e. United kingdom, the 273 Netherlands, and Singapore). After adjustment for population size (Table 5B), the 274 United States was downgraded to $9^{\text {th }}$ place, and China disappeared from the top 20 275 countries. The ranking positions changed overall in favor of smaller countries with a low 276 population size, with the appearance of Iceland, Switzerland, Denmark, and New 277 Zealand in the top 10 . When normalized by GDP (Table 5C), 10 of the top 20 countries 278 in terms of absolute production (number of articles produced), disappeared (i.e. China, , 279 Japan, Germany). Furthermore, the ranking positions changed in favor of some 280 developing countries (i.e. Malawi, Guatemala, Singapore ). Nine countries appeared in 281 the top 25 countries for the three parameters studied: the United States, United 282 Kingdom, the Republic of Korea, Spain, Australia, the Netherlands, Switzerland, Israel 283 and Singapore. 
Table 5 Twenty countries with publications related to eye diseases (2010-2014). (A) Based on the total number of 285 publications, (B) Based on the 5-Y IF population index (cumulative 5-Y IF per million inhabitants), (C) Based on the 5-Y IF 286 GDP index (cumulative 5-Y IF per 1 billion US dollars of GDP)

287

$288 \quad$ A

\begin{tabular}{|l|l|l|l|}
\hline Country & $\begin{array}{l}\text { No. of } \\
\text { articles (\%) }\end{array}$ & $\begin{array}{l}\text { Cumulative } \\
\text { 5-Y IF (sum } \\
\text { of 5-Y IF) }\end{array}$ & $\begin{array}{l}\text { m5-Y IF } \\
\text { (mean 5-Y } \\
\text { IF) }\end{array}$ \\
\hline United States & $\begin{array}{l}15266 \\
(25.85)\end{array}$ & 53328.643 & 3.49 \\
\hline China & $4967(8.41)$ & 11319.11 & 2.28 \\
\hline $\begin{array}{l}\text { United } \\
\text { Kingdom }\end{array}$ & $4141(7.01)$ & 14502.337 & 3.50 \\
\hline Japan & $4029(6.82)$ & 9644.649 & 2.39 \\
\hline Germany & $3247(5.5)$ & 7569.76 & 2.33 \\
\hline India & $2288(3.87)$ & 4259.227 & 1.86 \\
\hline Italy & $2200(3.73)$ & 6055.104 & 2.75 \\
\hline Korea. Rep. & $2137(3.62)$ & 5082.929 & 2.38 \\
\hline France & $2045(3.46)$ & 4896.101 & 2.39 \\
\hline Spain & $1820(3.08)$ & 4115.654 & 2.26 \\
\hline Turkey & $1682(2.85)$ & 2573.658 & 1.53 \\
\hline Australia & $1669(2.83)$ & 5152.254 & 3.09 \\
\hline Canada & $1377(2.33)$ & 4413.118 & 3.20 \\
\hline Brazil & $1005(1.7)$ & 1690.9 & 1.68 \\
\hline Netherlands & $861(1.46)$ & 3209.807 & 3.73 \\
\hline Switzerland & $757(1.28)$ & 1958.809 & 2.59 \\
\hline $\begin{array}{l}\text { Iran. Islamic } \\
\text { Rep. }\end{array}$ & $644(1.09)$ & 1213.767 & 1.88 \\
\hline & & & \\
\hline
\end{tabular}

B

\begin{tabular}{|l|l|}
\hline Country & $\begin{array}{l}\text { 5-Y IF } \\
\text { population } \\
\text { index }\end{array}$ \\
\hline Iceland & 567.11 \\
\hline Singapore & 376.18 \\
\hline Switzerland & 246.27 \\
\hline $\begin{array}{l}\text { United } \\
\text { Kingdom }\end{array}$ & 228.55 \\
\hline Australia & 228.41 \\
\hline Denmark & 205.73 \\
\hline Israel & 204.07 \\
\hline Netherlands & 192.01 \\
\hline United States & 170.53 \\
\hline New Zealand & 163.37 \\
\hline Austria & 140.55 \\
\hline Finland & 130.29 \\
\hline Sweden & 128.62 \\
\hline Canada & 127.68 \\
\hline Greece & 108.60 \\
\hline Korea. Rep. & 101.96 \\
\hline Italy & 101.75 \\
\hline
\end{tabular}

C

\begin{tabular}{|l|l|}
\hline Country & $\begin{array}{l}\text { 5-Y IF GDP } \\
\text { Index }\end{array}$ \\
\hline Iceland & 12.65 \\
\hline Malawi & 11.43 \\
\hline & \\
Guatemala & 10.90 \\
\hline & \\
Singapore & 7.20 \\
\hline Israel & 6.16 \\
\hline United Kingdom & 5.64 \\
\hline Greece & 4.46 \\
\hline New Zealand & 4.35 \\
\hline Korea. Rep. & 4.21 \\
\hline Tunisia & 4.16 \\
\hline Nepal & 3.96 \\
\hline Netherlands & 3.77 \\
\hline Australia & 3.66 \\
\hline Denmark & 3.48 \\
\hline United States & 3.36 \\
\hline Turkey & 3.30 \\
\hline Switzerland & 2.98 \\
\hline
\end{tabular}




\begin{tabular}{|c|c|c|c|c|c|c|c|}
\hline Poland & $627(1.06)$ & 658.179 & 1.05 & Norway & 98.12 & Spain & 2.90 \\
\hline Israel & $589(1)$ & 1599.869 & 2.72 & Germany & 93.27 & Hungary & 2.89 \\
\hline Singapore & $550(0.93)$ & 1972.32 & 3.59 & Spain & 88.16 & Serbia & 2.89 \\
\hline
\end{tabular}

289 GDP = gross domestic product; 5-Y IF = five-year impact factor; $\mathrm{m5}$ - $\mathrm{Y} \mathrm{IF}=$ mean five-year impact factor 


\section{DISCUSSION}

293 To our knowledge, there are no similar studies examining worldwide research related to

294 ophthalmology, and such an analysis of articles related to eye diseases has never been

295 done. The MeSH term "Eye diseases" was chosen to retrieve articles in PubMed

296 because it reflects an extensive coverage of eye diseases. Although it would have been

297 easier and less complex to analyze MeSH terms without considering their position in the

$298 \mathrm{MeSH}$ tree (located or not beneath eye diseases), we showed that separate analysis

299 was more informative than not considering the position. In the former case, we would

300 have identified only 5 eye diseases (Vision Disorders, Glaucoma, Diabetic Retinopathy,

301 Macular Degeneration, and Cataract). In contrast, including the position in the MeSH

302 tree allowed us to identify the 20 most frequent topics related to eye diseases such as

303 diagnostic techniques, physiological phenomena, anatomic structures, and methods of

304 investigation. We also performed an analysis of co-occurring terms for the 20 most

305 frequent MeSH terms located beneath the MeSH term "Eye Diseases". To the best of

306 our knowledge, such an analysis has never been performed, and no study has defined,

307 individually, the topics related to the 20 most frequent eye diseases in the literature over

308 the 5-year study period. We could have chosen another MeSH term upon which to build

309 our query in PubMed for this analysis: "Ophthalmology", whose definition in the NLM-

310 controlled vocabulary thesaurus is "A surgical specialty concerned with the structure

311 and function of the eye and the medical and surgical treatment of its defects and

312 diseases". Using this MeSH term instead of "Eye Diseases" over the 5-year study period 
313 would have resulted in the analysis of only 734 articles, instead of the 62123 articles

314 included in the present study. This shows that the MeSH term "Ophthalmology" is not

315 adequate for retrieving articles in the field of ophthalmology using PubMed.

316 Our study proposes a quantitative evaluation, i.e. the number of articles published by a

317 journal and a qualitative evaluation based on the 5-Y IF , which takes into account the 318 average number of citations of articles published by a journal in a 5-year period. Note 319 that using the 5-Y IF is more qualitative, but does not reflect individual citations of 320 articles. PubMed was chosen because of its open access, broad coverage, international 321 visibility, quality criteria, and because it uses a controlled vocabulary thesaurus for 322 indexing and retrieving documents (Ramos, González-Alcaide \& Bolaños-Pizarro, 323 2013). However our methodology has several limitations: 1) PubMed is the most widely 324 used database for bibliometric analysis, but it does not contain all biomedical journals 325 and is biased in favor of English journals (Ugolini et al., 2007; Vioque et al., 2009), 2) 326 The methodology for identifying authors' country affiliations did not allow us to assess 327 the country for all articles studied. Furthermore, because the PubMed database indexes 328 only the affiliation of the first author before the year 2014, when present the country 329 affiliation of the authors indicated only one country per article and fails to identify 330 collaborative research, 3) Attributing the credit of articles completely to the first author 331 may also not always indicate the country in which the research was conducted, and 332 consequently may lead to underestimation of the research output in developed 333 countries. Indeed, the first author, in some cases, may be a student from a developing 334 country doing short-term research training in a developed country, whereas the last 335 author is most often the person who supervises and provides the most funding support 
336 for the project in a developed country. Despite these limitations and because 62123

337 articles were included, we believe that this study provides a wide view of scientific

338 productivity related to the field of ophthalmology during the period 2010-2014.

339 Moreover, since a part of the methodology used for this study has been used by other

340 authors, some of our results may be compared with those of others in the future (Ramos

341 et al., 2008; Vioque et al., 2009; Ramos, González-Alcaide \& Bolaños-Pizarro, 2013).

342 The articles retrieved in this study were published in 3368 journals, including 54 of 58

343 journals indexed in the category "Ophthalmology" in the JCR. Logically, 18 of 19 of the

344 core journals according to Bradford's law were included in the category

345 "Ophthalmology" in the JCR. PLoS One, belonging to the JCR category

346 "Multidisciplinary sciences", has published the lowest percentage of articles related to

347 eye diseases relative to the total number of articles produced $(1.23 \%)$. For the other

348 journals, the percentage of articles related to eye diseases relative to the total number

349 of articles produced varied from $58.14 \%$ (Experimental Eye research) to $91.86 \%$

350 (Ophthalmology). We found that no journal attained $100 \%$ articles related to eye

351 diseases because journals also publish articles related to investigational methods, basic

352 science such as cell biology, molecular biology, and cellular experimental topics.

353 Although these results may seem logical, we did not find similar results in the literature.

354 The United States, as expected, regardless of the scientific specialty or sub-specialty 355 considered, was by far the most absolute productive country. However, when 356 comparing our results with former studies in Ophthalmology (Ohba, 2005; Guerin et al., 357 2009), China experienced spectacular growth and is now the second most absolute 
358 productive country. Unexpectedly, the Islamic Republic of Iran appeared in the top 20 359 absolute productive countries in ophthalmology which may be explained by the high 360 annual average growth rate of $67 \%$ of Iranian publications related to ophthalmology 361 during the period 2001 to 2010 (Katibeh, Moein \& Javadi, 2011). The qualitative 362 evaluation using m5-Y IF did not reflect the absolute production (number of articles 363 produced), demonstrating the usefulness of considering this parameter for evaluating 364 scientific production of countries. When normalized by population, the overall ranking 365 positions changed in favor of developed countries and also in favor of smaller countries 366 with a small population size. Furthermore, as found in other studies (Ugolini et al., 2001; 367 Robert et al., 2004; Ohba, 2005; Albayrak et al., 2012; Boudry \& Mouriaux, 2015), 368 Nordic European countries were efficient when adjustment was made for population. 369 When normalized by GDP, the ranking positions changed partially in favor of developing 370 countries. The reason for this observation is difficult to interpret, but a better utilization 371 of resources may be the reason (Ugolini et al., 2007). 


\section{REFERENCES}

374 Albayrak Ö., Föcker M., Wibker K., Hebebrand J. 2012. Bibliometric assessment of 375 publication output of child and adolescent psychiatric/psychological affiliations 376 377 between 2005 and 2010 based on the databases PubMed and Scopus. European Child \& Adolescent Psychiatry 21:327-337.

378 379

Boudry C. 2015. Web 2.0 Applications in Medicine: Trends and Topics in the Literature. Medicine 2.0 4:e2.

Boudry C., Mouriaux F. 2015. Eye neoplasms research: a bibliometric analysis from 1966 to 2012. European Journal of Ophthalmology 25:357-365.

Chen H., Chen $\mathrm{CH}$. , Jhanji V. 2013. Publication Times, Impact Factors, and Advance Online Publication in Ophthalmology Journals. Ophthalmology 120:1697-1701.

Deshazo JP., Lavallie DL., Wolf FM. 2009. Publication trends in the medical informatics literature: 20 years of "Medical Informatics" in MeSH. BMC medical informatics and decision making 9:7.

Falagas ME., Pitsouni El., Malietzis GA., Pappas G. 2008. Comparison of PubMed, Scopus, Web of Science, and Google Scholar: strengths and weaknesses. The FASEB Journal: Official Publication of the Federation of American Societies for Experimental Biology 22:338-342.

Garfield E. 1972. Citation analysis as a tool in journal evaluation. Science 178:471-479. 
392 Geisler E. 2000. The metrics of science and technology. Westport, Conn.: Quorum $393 \quad$ Books.

394 Glynn RW., Chin JZ., Kerin MJ., Sweeney KJ. 2010. Representation of Cancer in the 395 Medical Literature - A Bibliometric Analysis. PLoS One 5:e13902.

Goffman W., Warren KS. 1969. Dispersion of papers among journals based on a 397 mathematical analysis of two diverse medical literatures. Nature 221:1205-1207.

398 399

400 401 402 403 404 405 406 407 408 409 410

Guerin B., Flynn H., Brady J., O’Brien C. 2009. Worldwide geographical distribution of ophthalmology publications. International ophthalmology 29:511-516.

Gupta BM., Bala A., Gupta. 2014. World Research Output in Conjunctivitis Research: A Quantitative Analysis during 2002-11. Collnet Journal of Scientometrics and Information Management 7:261-275.

Hirsch JE. 2005. An index to quantify an individual's scientific research output. Proceedings of the National Academy of Sciences of the United States of America 102:16569-16572.

Katibeh M., Moein H-R., Javadi M-A. 2011. Contribution of Iran to the Ophthalmic Literature over the Past Three Decades. Journal of Ophthalmic \& Vision Research 6:225-226.

Kondilis BK., Kiriaze IJ., Athanasoulia AP., Falagas ME. 2008. Mapping Health Literacy Research in the European Union: A Bibliometric Analysis. PLoS ONE 3:e2519. 
411 Kumaragurupari R., Sieving PC., Lalitha P. 2010. A bibliometric study of publications by 412 Indian ophthalmologists and vision researchers, 2001-06. Indian journal of 413 ophthalmology 58:275-280.

414 Kumar A., Cheeseman R., Durnian JM. 2011. Subspecialization of the ophthalmic 415 literature: a review of the publishing trends of the top general, clinical ophthalmic $416 \quad$ journals. Ophthalmology 118:1211-1214.

417 Kumbar M., Akhtary S. 1998. Bibliometric analysis of ophthalmology literature. Library 418 Science with a Slant to Documentation and Information Studies 35:201-207.

419 Liesegang TJ. 2011. The International American Journal of Ophthalmology. American $420 \quad$ journal of ophthalmology 152:1-2.e2.

421 MEDLINE Indexing Online Training Course 2015. Available at

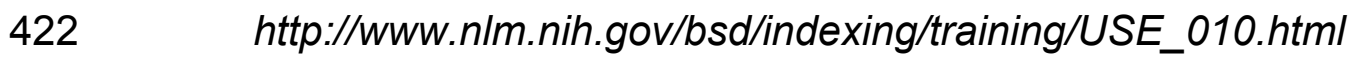

423 Michon F., Tummers M. 2009. The Dynamic Interest in Topics within the Biomedical $424 \quad$ Scientific Community. PLoS ONE 4:e6544.

425 Monica Neri DM. 2015. Worldwide interest in the comet assay: a bibliometric study. $426 \quad$ Mutagenesis 1:155-163.

427 Ohba N. 2005. [Bibliometric analysis of the current international ophthalmic $428 \quad$ publications]. Nippon Ganka Gakkai zasshi 109:115-125. 
429 Ramos JM., Padilla S., Masiá M., Gutiérrez F. 2008. A bibliometric analysis of 430 tuberculosis research indexed in PubMed, 19972006. The International Journal of Tuberculosis and Lung Disease 12:1461-1468.

432 Ramos JM., González-Alcaide G., Bolaños-Pizarro M. 2013. Bibliometric analysis of 433 leishmaniasis research in Medline (1945-2010). Parasite Vector 6:55.

434 Robert C., Arreto C-D., Azerad J., Gaudy J-F. 2004. Bibliometric overview of the 435 436 utilization of artificial neural networks in medicine and biology. Scientometrics 59:117-130.

437 438

439

440

441 442

443

444 445 446 447 448 ophthalmology departments in top 10 ophthalmology and vision science journals from 2001 to 2010. Canadian Journal of Ophthalmology. Journal Canadien D’ophtalmologie 48:46-55.

Sweileh WM., Al-Jabi SW., Shanti YI., Sawalha AF., Sa'ed HZ. 2015. Contribution of Arab researchers to ophthalmology: a bibliometric and comparative analysis. SpringerPlus 4:1-7.

Ugolini D., Cimmino MA., Casilli C., Mela GS. 2001. How the European Union writes about ophthalmology. Scientometrics 52:45-58.

Ugolini D., Puntoni R., Perera FP., Schulte PA., Bonassi S. 2007. A bibliometric analysis of scientific production in cancer molecular epidemiology. Carcinogenesis 28:1774-1779. 
449 Ugolini D., Neri M., Casilli C., Ceppi M., Canessa PA., Ivaldi GP., Paganuzzi M., 450 Bonassi S. 2010. A bibliometric analysis of scientific production in mesothelioma research. Lung Cancer (Amsterdam, Netherlands) 70:129-135.

452 Venable GT., Shepherd BA., Roberts ML., Taylor DR., Khan NR., Jr PK. 2014. An

453 application of Bradford's law: identification of the core journals of pediatric 454 neurosurgery and a regional comparison of citation density. Child's Nervous System 30:1717-1727.

456 Vioque J., Ramos JM., Navarrete-Muñoz EM., García-de-la-Hera M. 2009. A 457 458 bibliometric study of scientific literature on obesity research in PubMed (19882007). Obesity Reviews 11:603-611.

459 460

461 462

463 464

465 466

Wallace ML., Larivière V., Gingras Y. 2012. A Small World of Citations? The Influence of Collaboration Networks on Citation Practices. PLoS ONE 7:e33339.

Young H., Belanger T. 1983. The ALA glossary of library and information science. Chicago: American Library Association.

Zhao Z-G., Guo X-G., Xu C-T., Pan B-R., Xu L-X. 2011. Bibliometric analysis on retinoblastoma literatures in PubMed during 1929 to 2010. International journal of ophthalmology 4:115-120. 